\title{
The impact of working capital and financial structure on profitability of Islamic banking industry
}

\author{
Mohammad Khodaei Valahzaghard $^{a^{*}}$ and Ali Taherinejhad ${ }^{b}$
}

\author{
${ }^{a}$ Assist. Prof. \& Faculty Member, Department of Accounting, School of Management and Human Sciences, Tehran North Branch, Islamic Azad \\ University (IAU), Tehran, Iran \\ ${ }^{b}$ M.A. Student, Department of Accounting, School of Management, U.A.E Branch, Islamic Azad University (IAU), Iran

\section{A R T I C L E I N F O} \\ Article history: \\ Received March 29, 2012 \\ Received in Revised form \\ June, 12, 2012 \\ Accepted 25 June 2012 \\ Available online \\ June 302012 \\ Keywords: \\ Return of assets \\ Profitability

\section{A B S T R A C T} \\ In this paper, we present an empirical survey on selected Iranian banks operating actively from \\ 2005 to 2010. The proposed study considers the impacts of four important factors including \\ degree of financial leverage, bank size, working capital and liquidity on return on asset as a \\ primary source of measuring profitability of Iranian banking system. The survey uses Pearson \\ correlation test along with simple and multi regression analysis to study the behavior of these \\ four factors on profitability of banking system. Based on the results of this survey, a high level \\ of working capital and financial leverage will result to lower profitability in Iranian private \\ banks.
}

Financial structure

Financial leverage

\section{Introduction}

Banking system plays an important role on today's world economy and any serious challenge in banking industry influences the whole economy, significantly. One of financial turmoil goes back year 2008 where most banks in United States faced with serious disruption. During the past few years, there have been tremendous efforts on detecting such challenges. Chen (2011) proposed a market-valued capital ratio as an indicator to study the riskiness of banks by examining the crosssectional relationship between the market-valued capital ratio and stock returns of listed Japanese banks. He reported that banks with lower market-valued capital ratios maintained higher returns on average than banks with higher market-valued capital ratios. Nevertheless, they explained that the negative impact between market-valued capital ratio and average stock returns could be attributed to changes in exposure to risk factors. They also reported the cross-sectional variation in market-valued capital ratios to systematic patterns in relative profitability by demonstrating that low market-valued 
capital ratio could signal persistently poor profitability. In the last part of Chen's results, we learned some evidence, which indicated that the market-valued capital ratio could indeed serve as a strong predictive indicator for bank's share performance during the financial crisis in the late 1990s, even after controlling for a variety of other conventional risk measures.

Delis et al. (2012) tried to quantify the heterogeneous response of banks towards this type of regulation in banking sectors of western-type economies. They examined the sources of heterogeneity and their findings recommended that the effect of capital regulation on bank risk was very heterogeneous across banks and the sources of this heterogeneity could be traced into both bank and industry characteristics, as well as into macroeconomic conditions. An important application of the findings is that common capital regulatory umbrellas are not enough to facilitate financial stability, especially if they are not supported by supervisory effectiveness .

Loutskina (2011) overviewed the role of securitization in bank management by proposing a new index of "bank loan portfolio liquidity" as a weighted average of the potential to securitize loans of a given type, where the weights reflect the combination of a bank loan portfolio. The proposed new index seems to demonstrate that by permitting banks to convert illiquid loans into liquid funds, securitization reduces banks' holdings of liquid securities and increases their lending abilities. In addition, securitization provides banks with an additional source of funding and makes bank lending less sensitive to expenditure of funds shocks .

Recently, there are some evidences that lines of credit are an imperfect substitute for cash as a source of corporate liquidity. Demiroglu and James (2011) reviewed different evidences on the use of bank lines of credit as a source of corporate liquidity. While, many had thought lines of credit as a kind of insurance against liquidity shocks but their empirical research revealed another issue. In fact, in recent years, access to lines of credit was contingent on the credit quality of the borrower as well as the financial condition of the lender .

Fields et al. (2012) investigated the relationship between comprehensive measures of board quality, the cost and the non-price terms of bank loans. They explained that firms with higher quality boards and a greater advisory presence borrow at lower interest rates. This relationship exists even after controlling for ownership structure, CEO compensation policy, and shareholder protection, the size and financial characteristics of the borrower and of the loan. They also explained some evidence that board quality and other governance characteristics impact the likelihood that loans have covenant requirements, but the relationships differ by covenant type .

van den End, J.W., and Tabbae (2012) provided empirical evidence of behavioural responses by banks in the recent crisis. The built aggregate indicators of systemic risk based on firm-specific balance sheet data. Their results indicated that balance sheet adjustments have been pro-cyclical in the crisis, while responses was increasingly dependent across banks and concentrated on certain market segments .

Ariff and Can (2008) studied profitability of 28 Chinese commercial banks by examining the impact of ownership type, size, risk profile, profitability and key environmental changes on the bank efficiency using a Tobit regression. Consistent with the existing literature, they reported that profit efficiency levels were well below those of cost efficiency. They explained that the most important inefficiencies were on the revenue side. The findings seemed to be consistent with prior evidence on ownership and efficiency including joint-stock banks, on average, appeared to be more cost-and profit-efficient than state-owned banks while medium-sized banks are significantly more efficient than small and large banks. They recommended for speedier reforms to open the banking market, improving risk management, minimizing the government's capital subsidy and diversifying ownership of Chinese banks. 
Akhigbe and McNulty (2011) performed a survey on a bank-specific, fixed-effects regression model to develop proxies for a bank's monitoring effort. Their results showed that banks that devote more resources to monitoring were more profit efficient and the effect was large. A very important theoretical literature in finance recommended that monitoring is value enhancing. They established an important link between the large literature on bank monitoring and the equally large literature on profit efficiency.

\section{The proposed model}

The proposed study of this paper uses the information of 19 different active banks from year 2005 to year 2010. We use regression analysis where the independent variables are degree of financial leverage (DFL), bank size (Size), working capital (CAP_WOR) and liquidity (Liquidity) and profitability (Profit) is the dependent variable and the regression model is as follows,

Profit $i, t=\beta 0+\beta 1$ DFLi, $t+\beta 2$ Sizei, $\mathrm{t}++\beta 4$ Liquidityi, $t+\beta 5 \mathrm{CAP}$ WOR $i, t+\varepsilon i, t$

In terms of ownership, we could divide the banks into three groups of private, governmental and a combination of these two. Note that during the past few years, the government of Iran has privatized most of the Iranian banks in an attempt to reduce government size. Table 1 shows different characteristics of 114 banks in terms of their return of assets (ROA), working capital, DFL, size and liquidity.

\section{Table 1}

Financial characteristics of banks

\begin{tabular}{lccccccc}
\hline & & & & & \multicolumn{2}{c}{ deviation } \\
Var. & Mean & Standard deviation & Variance & Skewness & Strain & Skewness & Strain \\
\hline ROA & 0.015 & 0.014 & 0.000 & 1.435 & 2.850 & 6.335 & 6.344 \\
Working capital & 97.219 & 113.37 & 12852.93 & 2.134 & 6.353 & 9.422 & 14.140 \\
DFL & 0.872 & 0.215 & 0.046 & -1.768 & 8.925 & -7.805 & 19.867 \\
Size & 4.861 & 0.604 & 0.365 & -0.278 & -0.827 & -1.229 & -1.842 \\
Liquidity & 1423.623 & 86.09 & 7412.219 & 3.680 & 14.940 & 16.247 & 33.255 \\
\hline
\end{tabular}

Since the gathered information are formed on a year-bank format and the purpose of this survey is to learn the effects of independent variables on dependent variable we use first test period fix effect using Chow statistical test on intercept and slope of each bank. We first use period random effect and in case, null hypothesis has meaningful effect we use fixed effect, otherwise we use random effect. One of other non-parametric assumptions of using non-parametric test is the normality of variables. In order to test normality we use Kolmogorov-Smirnov, Shapiro-Wilk and Jarque- bera tests. The level of significance is small for the first two tests which means the variables are not normally distributed and based on the last test distribution of bank size is normal and others are not. Table 2 shows details of the results.

Table 2

Normality test using three methods

\begin{tabular}{lccccccc}
\hline & & \multicolumn{2}{c}{ Kolmogorov-Smirnov } & \multicolumn{2}{c}{ Shapiro-Wilk } & \multicolumn{2}{c}{ Jarque- bera } \\
\hline Variable & Number & k-s & Sig & s-w & Sig & j-b & Sig \\
\hline ROA & 114 & .136 & .000 & .877 & .000 & 72.05239 & 0.000000 \\
Working capital & 114 & .197 & .000 & .771 & .000 & 256.6681 & 0.000000 \\
DFL & 114 & .294 & .000 & .627 & .000 & 399.9100 & 0.000000 \\
Size & 114 & .087 & .035 & .970 & .012 & 4.815047 & 0.090038 \\
Liquidity & 114 & .301 & .000 & .521 & .000 & 1213.820 & 0.000000 \\
\hline
\end{tabular}

\subsection{Chow and Hausman test}

Since we deal with multi variable regression analysis, we need to determine the status of regression intercepts and slops of banks. In order to use unique or different intercepts we use Chow test. When 
all intercept are equal we use pooled method, otherwise we use panel method. According to Hausman test (Davidson \& MacKinnon, 1993), if random effects are rejected we use fixed effect, otherwise we use random effect. The results of Chow test implies that we should use panel method and Hausman method recommends fixed effect. Table 3 shows details of our tests.

Table 3

The results of Haman and Chow tests

\begin{tabular}{llllllll}
\hline Model & Test & \multicolumn{3}{c}{ Chow test } & \multicolumn{2}{c}{ Hausman Test } \\
\cline { 2 - 8 } hypothesis & specification & F & Error & Result & $\chi$ & Error & Result \\
\hline Main & Pooled & 1.263715 & 0.2852 & Equal intercept & & & \\
hypothesis & Panel & 4.359289 & 0.0000 & Unequal slop & 0.000000 & 1.0000 & Random effects \\
\hline $\begin{array}{l}\text { Sub } \\
\text { hypothesis }\end{array}$ & Pooled & 2.649445 & 0.0269 & $\begin{array}{l}\text { Unequal } \\
\text { intercept }\end{array}$ & 12.503409 & 0.0140 & Fixed effect \\
& Panel & 6.724017 & 0.0000 & Unequal slop & 5.743813 & 0.2191 & Random effects \\
\hline
\end{tabular}

The other primary assumption of all parametric tests is to have linear relationship between independent variables and dependent variable and F-statistic confirms this issue. In other words, the level of significance indicates that there is a linear relationship between independent variables of dependent variable. Another test is to see whether residuals are normality distributed or not and Table 4 shows details of our survey. As we can observe from the results of Table 4 we cannot claim that residuals are normally distributed according to Jarque-bera test when the level of significance is five percent. The other test for the survey is to see whether there is any correlation between residual and Durbin Watson (DW) test is one of the most popular tests to verify this issue. As we can observe from the results, all DW tests are located within acceptable limit, which means there is no correlation among residuals.

\section{Table 4}

The results of different statistics

\begin{tabular}{lccccc}
\hline Model & \multicolumn{2}{c}{ Linear relationship } & Durbin Watson test & \multicolumn{2}{c}{ Residual } \\
\cline { 2 - 6 } & F & Sig. & D.W. & J_B statistics & Sig. \\
\hline Main model & 10.50198 & 0.000004 & 1.923716 & 108.0427 & 0.000000 \\
Sub-model & 3.597646 & 0.000621 & 1.846785 & 7.278424 & 0.026273 \\
& 4.639911 & 0.000019 & 1.873796 & 17.97805 & 0.000125 \\
\hline
\end{tabular}

Finally, before we analyze the results of the regression estimation we need to study collinearity among all independent variables. In fact, when there is a strong correlation between independent variables, we face with collinearity issue and cannot trust the final results (See Table 5).

\section{Table 5}

The results of Pearson correlation test when the level of significance is five percent

\begin{tabular}{lcccc}
\hline Variable & Working capital & DFL & Size & Liquidity \\
\hline Working capital & 1 & 0.256 & 0.796 & 0.642 \\
DFL & 0.256 & 1 & 0.357 & 0.138 \\
Size & 0.796 & 0.357 & 1 & 0.574 \\
Liquidity & 0.642 & 0.138 & 0.574 & 1 \\
\hline
\end{tabular}

As we can see from the results of our survey, there is not a significant correlation between any pairs of independent variables.

\section{Data analysis and results}

In order to test the hypothesis of this survey we have considered two models. In the main model, the effect of two independent variables of working capital and DFL along with a dummy variable, which represents ownership type, is considered on return on asset (ROA). The results of Chow and Hausman tests supported us to use random effects along with pooled method for different years. Durbin-Watson (DW) test results indicate that there was no auto correlation among residuals. F- 
statistic is statistically meaningful when the level of significance is five percent, which means there is a linear relationship between independent variable and dependent variable. All t-student values for three independent variables of working capital, DFL and dummy variable (DU) are meaningful. Finally, $R^{2}$ shows that the regression independent variables of the model represent 22 percents of changes of the profitability.

\section{Table 6}

The results of the first regression model

\begin{tabular}{ccccccc}
\hline & & & coefficient & Standard deviation & t-student & P-value \\
\hline$\beta_{0}$ & Intercept & $\mathrm{C}$ & 0.020508 & 0.004439 & 4.619990 & 0.0000 \\
$\beta_{1}$ & Working capital & CAP-WOR & -0.00000003 & 0.00000001 & -3.203447 & 0.0018 \\
$\beta_{2}$ & DFL & LEV & -0.01022200 & 0.00474800 & -2.152849 & 0.0335 \\
$\beta_{3}$ & Ownership & DU & 0.01165400 & 0.00255500 & 4.562041 & 0.0000 \\
$\mathrm{R}^{2}=0.222, \mathrm{AdR}^{2}=0.201, \mathrm{~F}=10.501, \mathrm{D} . \mathrm{V}=1.923$, S.E.of regression $=0.0084$, Sum squared resid=0.0078 & \\
$\mathrm{ROA}=0.020508-0.00000003 *$ CAP-WOR -0.01022200*LEV $+0.01165400^{*} \mathrm{DU}+[\mathrm{CX}=\mathrm{R}]$ & \\
\hline
\end{tabular}

The second model considers DFL, size, Liquidity and working capital as independent variables and return on asset (ROA) as dependent variable. Again, all statistical observations including F, DW and $\mathrm{t}$-students are meaningful when the level of significance is five percent. Finally, $R^{2}$ shows that the regression independent variables of the model represent 24 percents of changes of the profitability. Table 7 demonstrates the results of the second regression model.

Table 6

The results of the first regression model

\begin{tabular}{|c|c|c|c|c|c|c|}
\hline & & & coefficient & Standard deviation & t-student & $\mathrm{P}$-value \\
\hline$\beta_{0}$ & Intercept & $\bar{C}$ & 0.069288 & 0.022417 & 3.090918 & 0.0026 \\
\hline$\beta_{1}$ & Working capital & CAP-WOR & -0.000000001 & 0.000000009 & -0.149296 & 0.8816 \\
\hline$\beta_{2}$ & DFL & LEV & -0.007574 & 0.006857 & -1.104662 & 0.2719 \\
\hline$\beta_{3}$ & Size & SIZE & -0.010537 & 0.004345 & -2.425046 & 0.0170 \\
\hline$\beta_{4}$ & Liquidity & LIQUDITY & -0.00000048 & 0.00000026 & -1.831250 & 0.0700 \\
\hline$\beta_{5}$ & Ownership & DU & 0.007965 & 0.002611 & 3.051085 & 0.0029 \\
\hline \multicolumn{7}{|c|}{$\mathrm{R} 2=0.31, \mathrm{AdR} 2=0.243, \mathrm{~F}=3.597, \mathrm{D} . \mathrm{V}=1.87$, S.E.of regression $=0.0079$, Sum squared resid $=0.0065$} \\
\hline \multicolumn{7}{|c|}{$\mathrm{ROA}=0.093723-0.0000000014 * \mathrm{CAP}-\mathrm{WOR}-0.0075 * \mathrm{LEV}-0.0105 * \mathrm{SIZE}-0.00000047 *$ LIQUDITY $+0.0079 * \mathrm{DU}+[\mathrm{CX}=\mathrm{R}, \mathrm{PER}=\mathrm{F}]$} \\
\hline
\end{tabular}

\subsection{Main hypothesis: Management of working capital and financial structure impact profitability of} private banks in Iran.

To test this hypothesis, we have used the first regression model earlier presented. Based on the results of this paper, we can conclude that as the working capital increases, profitability will reduce. The same holds for degree of financial leverage (DFL), i.e. as DFL increases, profitability will decrease. The results also confirm that ownership impacts profitability of banks, significantly.

\subsection{Sub hypotheses}

There are four hypotheses associated with the proposed study of this paper.

\subsubsection{Degree of financial leverage (LEV) has meaningful impact on return of assets (ROA)}

The Pearson correlation test between these two variables is -0.321 where the level of significance is 0.012 and it means there is a meaningful reverse relationship between these two variables. Other results indicate that about 10 percent of the changes on profitability are described by this variable.

\subsubsection{The size of bank has meaningful effect on return of assets (ROA)}

The Pearson correlation test between these two variables is -0.492 where the level of significance is 0.001 and it means there is a meaningful reverse relationship between these two variables. Other results indicate that about 24 percent of the changes on profitability are described by this variable. 


\subsubsection{Working capital has a meaningful impact on return on assets (ROA)}

The Pearson correlation test between these two variables is -0.438 where the level of significance is 0.001 and it means there is a meaningful reverse relationship between these two variables. Other results indicate that about 20 percent of the changes on profitability are described by this variable.

\subsubsection{Liquidity has a meaningful impact on return on assets (ROA)}

The Pearson correlation test between these two variables is -0.449 where the level of significance is 0.001 and it means there is a meaningful reverse relationship between these two variables. Other results indicate that about 19 percent of the changes on profitability are described by this variable.

\section{Conclusion}

Profitability in every business unit is the results of different financial activities such as investment, resource allocation, etc. In this paper, we have considered the impact of four important factors including degree of financial leverage, bank size, working capital and liquidity on return on asset as a primary source of profitability of Iranian banking system. Table 7 shows details of our findings for the main and sub-hypotheses of the paper.

\section{Table 7}

The summary of testing different hypotheses of the survey

\begin{tabular}{|c|c|c|c|c|c|c|c|c|}
\hline & \multirow[b]{2}{*}{ Research variable } & & \multicolumn{2}{|c|}{ Pearson ratio } & \multicolumn{2}{|c|}{ Single regression } & \multicolumn{2}{|c|}{ Multi-regression } \\
\hline & & & $\mathrm{H}_{0}$ & $\mathrm{H}_{1}$ & $\mathrm{H}_{0}$ & $\mathrm{H}_{1}$ & $\mathrm{H}_{0}$ & $\mathrm{H}_{1}$ \\
\hline & Independent variable & Dependent variable & $\mathrm{r}=0$ & $r \neq 0$ & $\mathrm{~B}=0$ & $\mathrm{~B} \neq 0$ & $\mathrm{~B}=0$ & $\mathrm{~B} \neq 0$ \\
\hline Main & working capital \& financial leverage & ROA & $x$ & $\checkmark$ & $x$ & $\checkmark$ & $\checkmark$ & $\checkmark$ \\
\hline H1 & financial leverage & ROA & $\mathbf{x}$ & $\checkmark$ & $\mathbf{x}$ & $\checkmark$ & $\checkmark$ & $\checkmark$ \\
\hline $\mathrm{H} 2$ & size & ROA & $x$ & $\checkmark$ & $x$ & $\checkmark$ & $\checkmark$ & $x$ \\
\hline $\mathrm{H} 3$ & working capital & $\mathrm{ROA}$ & $x$ & $\checkmark$ & $x$ & $\checkmark$ & $\checkmark$ & $x$ \\
\hline $\mathrm{H} 4$ & Liquidity & ROA & $x$ & $\checkmark$ & $x$ & $\checkmark$ & $\checkmark$ & $x$ \\
\hline
\end{tabular}

Based on the results of this survey, a high level of working capital and financial leverage will result to lower profitability in Iranian private banks.

\section{References}

Akhigbe, A., \& McNulty, J.E. (2011). Bank monitoring, profit efficiency and the commercial lending business model. Journal of Economics and Business, 63(6), 531-551.

Ariff, M., \& Can, L. (2008). Cost and profit efficiency of Chinese banks: A non-parametric analysis. China Economic Review, 19(2), 260-273.

Chen, S. (2011). Capital ratios and the cross-section of bank stock returns: Evidence from Japan. Journal of Asian Economics, 22(2), 99-114.

Davidson, R., \& MacKinnon, J. G. (1993). Estimation and Inference in Econometrics. New York: Oxford University Press.

Delis, M.D., Tran, K.C., Tsionas, E.G. (2012). Quantifying and explaining parameter heterogeneity in the capital regulation-bank risk nexus. Journal of Financial Stability, 8(2), 57-68.

Demiroglu, C., \& James, C. (2011). The use of bank lines of credit in corporate liquidity management: A review of empirical evidence. Journal of Banking \& Finance, 35(4), 775-782.

Fields, L.P., Fraser, D.R., \& Subrahmanyam, A. (2012). Board quality and the cost of debt capital: The case of bank loans. Journal of Banking \& Finance, 36(5), 1536-1547.

Loutskina, E. (2011). The role of securitization in bank liquidity and funding management. Journal of Financial Economics, 100(3), 663-684.

van den End, J.W., \& Tabbae, T. (2012). When liquidity risk becomes a systemic issue: Empirical evidence of bank behaviour. Journal of Financial Stability, 8(2), 107-120. 